\title{
MODUL SAINS KOMIK (MOSAKO) BERBASIS SCIENCE TECHNOLOGI ENGENERING AND MATHEMATIC (STEM) UNTUK SISWA SEKOLAH DASAR
}

\author{
${ }^{1}$ Winarto, ${ }^{2}$ Diyah Ayu Retnoningsih, ${ }^{3}$ Dwi Hesty Kristyaningrum,
}

1,2,3 Universitas Peradaban

\begin{tabular}{|c|c|}
\hline Article Info & ABSTRACT \\
\hline Article history: & $\begin{array}{l}\text { The results of education in Indonesia are considered unsuccessful, especially at } \\
\text { the primary and secondary levels. The Program for International Students }\end{array}$ \\
\hline $\begin{array}{l}\text { Received Maret 17, } 2021 \\
\text { Accepted April 26, } 2021 \\
\text { Published April, } 2021\end{array}$ & $\begin{array}{l}\text { Assessment (PISA) assessment of the literacy abilities (mathematics, science, } \\
\text { and language) of students from around the world respectively in } 2003,2006 \text {, } \\
2009 \text { and 2012. The purpose of this study was to develop a science comic module } \\
\text { media approach. STEM for grade V students. This type of research is Research } \\
\text { and Development (R\&D) research. The development model used is 4D from }\end{array}$ \\
\hline Keywords: & $\begin{array}{l}\text { Thiagarajan (1974). The sampling technique used is purposive sampling. Data } \\
\text { collection techniques using interviews, questionnaires and tests. Data analysis }\end{array}$ \\
\hline $\begin{array}{l}\text { Development, MOSAKO, } \\
\text { STEM, Literacy, Elementary } \\
\text { School }\end{array}$ & $\begin{array}{l}\text { using descriptive statistics. The research results obtained (1) MOKOSA media } \\
\text { needs to be developed based on a preliminary study, there are no media that } \\
\text { packs comics and STEM. (2) STEM-based MOKOSA is feasible and valid based } \\
\text { on the results of media validation, material and student responses with very good } \\
\text { categories. } \\
\text { Keywords: Development. MOSAKO, STEM, Literacy, Elementary School }\end{array}$ \\
\hline
\end{tabular}

\section{Corresponding Author:}

\section{Winarto}

Fakultas Keguruan dan Ilmu Pendidikan

Universitas Peradaban

Jl. Raya KM 03 Pagojengan Paguyangan, Brebes, Indonesia

Email: wiwin16@gmail.com,

\section{How to Cite:}

Winarto., Retnoningsih, DA., dan Kristyaningrum, DH. (2021). Modul Sains Komik (Mosako) Berbasis Science Technologi Engenering And Mathematic (STEM) Untuk Siswa Sekolah Dasar. Khazanah Pendidikan-Jurnal Ilmiah Kependidikan (JIK), 15(1), 51-64 and conditions of the Creative Commons Attribution License (http://creativecommons.org/licenses/by/4.0/). 


\section{PENDAHULUAN}

Hasil pendidikan di Indonesia dinilai belum berhasil, khusunya di jenjang pendidikan dasar dan menegah. Tjalla (2010) mengungkapkan penelitian yang dilakukan oleh Programme for International Students Assessment (PISA) terhadap kemampuan literasi (matematika, sains, dan bahasa) siswa dari berbagai dunia berturut-turut pada tahun 2003, 2006, 2009, dan 2012. Penelitian yang dilakukan oleh Progress in International Reading Literacy Study (PIRLS) pada tahun 2006. PIRLS melakukan kajian terhadap 45 negara maju dan berkembang dalam bidang membaca pada anak-anak kelas IV sekolah dasar di seluruh dunia di bawah koordinasi The International Association for the Evaluation of Educational Achievement (IEA) dan memperoleh hasil yang menempatkan Indonesia pada peringkat ke 41. Purwanto (Nurdiyanti, 2010) faktor rendahnya literasi sains siswa SD berhubungan dengan sekolah dasar, sistem persekolahan masih kurang memberi peluang bagi tradisi literasi kepada peserta didik. Model pengajaran di kelas disampaikan dengan pendekatan teacher center yang memposisikan siswa sebagai pendengar. Permasalahan dalam penelitian ini yaitu bagaimana menghasilkan media pembelajaran yang dapat meningkatkan literasi sains siswa SD. Tujuan khusus dalam penelitian ini yaitu menghasilkan MOSAKO (modu sains komik) berbasis STEM yang sudah melalui tahap pengembangan dan pengujian sehingga diperoleh produk yang valid.

Penelitian terdahulu tentang modul untuk siswa sekolah dasar dapat meningkatkan hasil belajar siswa. Hasil penelitian Nisa, Sarmini, Sudarmin (2015) disimpulkan bahwa siswa yang diajar dengan menggunakan modul terintegrasi etnosains dalam pembelajaran berbasis masalah memiliki kemampuan literasi sains lebih tinggi dibanding dengan kemampuan literasi sains kelas kontrol.Yanti, Sudarisman, Maridi (2016) disimpulkan bahwa karakteristik modul berbasis GIL sesuai sintaks GIL (observasi, manipulasi, generalisasi, verifikasi, dan aplikasi) dengan pendekatan sainstifik, layak, dan efektif untuk meningkatkan untuk meningkatkan literasi sains. Afriana, Permanasari, Fitriani (2016) tentang penerapan Project Based Learning terintegrasi STEM untuk meningkatkan literasi sains siswa. Rahmawati (2012) mengatakan bahwa strategi cerita sosial secara akurat mendeskripsikan situasi-situasi dan percakapan komik yang murni menggunakan simbolsimbol visual, konsep percakapan yang abstrak dan warna yang mengindikasi content emosional dapat meningkatkan pemahaman siswa. MOSAKO merupakan media pembelajaran yang baru dan berbeda. MOSAKO (Modul Sains Komik) merupakan bahan ajar yang disusun dengan gambar-gambar kartun terintegrasi pelajaran dan memuat konsep STEM melalui sebuah tema. Pengemasan materi yang mengkaji lebih dari satu bidang diduga membantu siswa mencari hubungan antar kajian dengan kehidupan sehari-hari dan materi dikemas dengan sebuah alur cerita. Penelitian tentang pengembangan MOSAKO dengan Pendekatan STEM, perlu dilakukan penelitian karena merupakan hal baru sesuai dengan program yang sudah dicanangkan pemerintah yaitu meningkatkan literasi siswa Indonesia.

Sains (IPA) merupakan salah satu ilmu yang dipelajari dengan metode ilmiah. Pembelajaran IPA mengutamakan proses penyeledikan. Oleh karena itu, dalam pembelajaran IPA membutuhkan media yang dapat menuntun siswa melakukan penyelidikan. Salah satu media yang dapat dipilih oleh guru yaitu modul. Darmiyatun, (2013:9) modul adalah bahan ajar yang dirancang secara sistematis berdasarkan kurikulum tertentu dan dikemas dalam bentuk satuan pembelajaran terkecil dan memungkinkan dipelajari secara mandiri dalam satuan waktu tertentu agar siswa menguasai kompetensi yang diajarkan. Berdasarkan kajian hasil penelitian terdahulu, modul memiliki peran penting dalam pencapaian hasil belajar siswa. Hasil penelitian Nisa, Sarmini, Sudarmin (2015) disimpulkan bahwa siswa yang diajar dengan menggunakan modul terintegrasi etnosains dalam pembelajaran berbasis masalah memiliki kemampuan literasi sains lebih tinggi 
dibanding dengan kemampuan literasi sains kelas kontrol.Yanti, Sudarisman, Maridi (2016) disimpulkan bahwa karakteristik modul berbasis GIL sesuai sintaks GIL (observasi, manipulasi, generalisasi, verifikasi, dan aplikasi) dengan pendekatan sainstifik fektif untuk meningkatkan untuk meningkatkan literasi sains. Kamala, Prayitno, Sudarisma (2015) disimpulkan penerapan modul IPA Terpadu berbasis Inquiry Lesson dapat meningkatkan literasi sains siswa. Berdasarkan kajian penelitian, modul efektif meningkatkan hasil belajar. Dalam penelitian ini, modul salah satu media pembelajaran yang dipilih untuk memfasilitasi siswa sekolah dasar dalam belajar.

Komik memiliki kontribusi yang besar dalam memberikan informasi yang mendidik, menghibur, sekaligus mempegaruhi seperti hakekat fungsi dari komunikasi (Maharsi, 2010: 10). Menurut Daryanto (2013: 128) kelebihan komik sebagai media pembelajaran, mengandung unsur visual dan cerita yang kuat. Ekspresi yang divisualisasikan membuat pembaca terlibat secara emosional membuat pembaca terdorong untuk membacanya hingga selesai.Penelitian yang dilakukan. Nugroho (2013) menyimpulkan komik sains yang dikembangkan juga terbukti efektif meningkatkan hasil belajar siswa. Penelitian Wijiati (2010) menyimpulkan multimedia komik pada pembelajaran matematika yang dikembangkan dapat digunakan sebagai sumber belajar siswa SD yang efektif. Penggunaan komik dipilih dalam penelitian ini sebagai strategi untuk meningkatkan motivasi belajar siswa. Tampilan gambar pada komik memperkuat informasi yang disampaikan. Karakteristik siswa SD yang lebih mudah belajar menggunakan media gambar untuk menjelaskan sebuah konsep, menjadi pertimbangan alasan pemilihan teknik komik. Rahmawati (2012) mengatakan bahwa strategi cerita sosial secara akurat mendeskripsikan situasi-situasi dan percakapan komik yang murni menggunakan simbol-simbol visual, konsep percakapan yang abstrak dan warna yang mengindikasi content emosional dapat meningkatkan pemahaman siswa.

Isi komik dalam MOSAKO yang berisi dominasi percakapan dalam bentuk gambargambar diduga akan memudahkan siswa dalam memahami materi. MOSAKO dikemas secara tematik yang berisi lebih dari satu kajian. Selain itu, penyusunan materi MOSAKO menggunakan sebuah alur cerita yang mengambil kejadian nyata dalam kehidupan seharihari. MOSAKO yang berisi lebih dari bahan kajian materi dan teknik komik diduga akan membantu siswa mempelajari materi dan keterkaitan antar bidang kajian sehingga diduga literasi siswa akan meningkat. Penelitian Haryadi\& Irawan (2016) menyimpulkan bahwa hal keterlibatan media komunikasi visual yang berperan sebagai pengemas cerita secara lebih menarik. Masing-masing media komunikasi visual baik berupa media statis seperti komik dan cerita bergambar serta media dinamis seperti animasi dan game bisa diadaptasi untuk mendukung kegiatan storytelling sesuai dengan pesan yang ingin disampaikan.

Pendekatan dan strategi pembelajaran mempunyai makna yang sama untuk menjelaskan bagaimana proses seorang guru mengajar dan peserta didik belajar dalam mencapai tujuan. Penggunaan kedua istilah ini sering dipertukarkan (Mulyatiningsih,2010:2). Pendekatan STEM diduga tepat untuk menyusun modul yang bertujuan meningkatkan literasi sains siswa. Permanasari (2016) penerapan STEM cocok digunakan pada pembelajaran sains. Pembelajaran berbasis STEM dapat melatih siswa dalam menerapkan pengetahuannya untuk membuat desain sebagai bentuk pemecahan masalah terkait lingkungan dengan memanfaatkan teknologi. Hasil penelitian Arfiana, Permanasari, Fitriani (2016) tentang penerapan Project Based Learning Terintegrasi STEM untuk Meningkatkan Literasi Sains Siswa Ditinjau dari Gender disimpulkan hasil terjadi peningkatan literasi sains siswa kelompok laki-laki dan kelompok perempuan sama- sama mengalami peningkatan dengan rerata N_Gainyaitu 0,36 dan 0,31pada kategori sedang untuk aspek pengetahuan dan kompetensi. Hasil penelitian Muharomah (2017) menyimpulkan terdapat pengaruh pembelajaran STEM terhadap hasil belajar siswa pada 
konsep evolusi. Ismayani (2016) disimpulkan bahwa terdapat perbedaan pencapaian kemampuan sebelum dan setelah pembelajaran berbeda secara signifikan. Ini artinya, penerapan pembelajaran STEM project-based learning yang dilakukan efektif dalam meningkatkan kemampuan berpikir kreatif siswa. Berdasarkan penelitian terdahulu, pendekatan STEM dapat meningkatkan hasil belajar dan keterampilan berpikir kreatif. Oleh karena itu, pendekatan STEM digunakan dalam mengemas MOSAKO.

MOSAKO yang dikembangkan mengacu pada aspek-aspek yang ada di pendekatan STEM. Menurut NCR (Winarni, Zubaedah, dan Supriyono, 2016:978) empat disiplin dan perannya dalam STEM sebagai berikut.

a. Sains ialah tubuh pengetahuan yang telah terakumulasi dari waktu ke waktu dari pemeriksaaan ilmiah yang mengahasilkan pengetahuan baru. Ilmu pengetahuan dari sains berperan menginformasikan proses rancangan teknik.

b. Teknologi ialah keseluruhan sistem dari orang dan organisasi, pengetahuan, proses dan perangkat-perangkat yang kemudian menciptakan benda dan mengoperasikannya. Manucia telah menciptakan teknologi untuk memuaskan keingian dan kebutuhannya.Banyak dari teknologi modern iadalah produk dari sains dan teknik.

c. Teknik merupakan tubuh pengetahuan tentang desain dan penciptaan benda buatan manusia dari sebuah proses untuk memecahkan masalah.Teknik memanfaatkan konsep dalam sains, matematika dan alat-alat teknologi.

d. Matematika adalah studi tentang pola dan hubungan antara jumlah, angka, dan ruang.Matematika digunakan dalam sains, teknik, dan teknologi.

Karkterisitk Siswa sekolah dasar dalam kegiatan belajar memerlukan obyek kokret, informasi yang utuh dan dekat dengan kehidupan sehari-hari. Rusman (2010:251-252) ketiga hal tersebut sebagai berikut: pertama, konkret maksudnya proses belajar beranjak dari halhal yang konkret dengan titik penekanan pada pemanfaatan lingkungan sebagai sumber belajar. Kedua, integratif maksudnya adalah memandang sesuatu yang dipelajari sebagai suatu keutuhan dan terpadu. Anak usia SD/MI belum mampu memilah-milah konsep dari berbagai disiplin ilmu, hal ini menggambarkan cara berpikir deduktif, keterpaduan konsep tidak dipilah-pilah dalam berbagai disiplin ilmu, tetapi dikait-kaitkan menjadi pengalaman belajar yang bermakna (meaningful learning). Ketiga, hierakhis maksudnya adalah berkembang secara bertahap mulai dari hal-hal yang sederhana ke hal-hal yang lebih kompleks. Oleh karena itu, dalam hal ini persoalanpersoalan seperti urutan logis, keterkaitan antar materi pelajaran, dan cakupan keluasan materi pelajaran menjadi penting dan sangat perlu untuk diperhatikan (Madjid, 2014:8).

Berkaitan dengan masalah penelitian mengenai rendahnya literasi sains siswa SD yang berhubungan dengan sistem persekolahan masih kurang memberi peluang bagi tradisi literasi kepada peserta didik. Melandasi tujuan pembuatan Modul Sains Komik (MOSAKO) berbasis Science Technologi Engenering and Mathematic (STEM) untuk meningkatkan Literasi Konten Sains Siswa Sekolah Dasar.

\section{METODE}

\section{a. Jenis Penelitian}

Penelitian ini merupakan jenis penelitian kuantitatif dengan menggunakan pendekatan Research and Development (R\&D). Produk yang dikembangkan dalam penelitian ini berupa media MOKOSA berbasis STEM. Model pengembangan yang digunakan dalam penelitian ini mengacu pada model ;.pengembangan 4D yang dikemukakan oleh Thiagarajan (1974) yang terdiri dari define, design, development, dan dissemination. 


\section{b. Waktu dan Tempat Penelitian}

Penelitian ini dilakukan dari 22 April sampai dengan 2 Oktober 2020. Tempat penelitian ini di SD yang berada di wilayah Brebes Selatan.

\section{c. Populasi dan Sampel}

Populasi dalam penelitian ini adalah Siswa seluruh siswa kelas 5 di SD kecamatan Bumiayu. Teknik pengambilan sampel yang digunakan adalah purpossive sampling. Purpossive sampling adalah teknik penentuan sampel dengan pertimbangan tertentu. Sampel dalam penelitian ini adalah siswa kelas V SD Islam T Hudda.

\section{d. Prosedur Penelitian}

Langkah - langkah penelitian yang dilakukan dalam penelitian ini mengacu pada langkah-langkah pengembangan pada model 4D yang dikemukakan oleh Thiagarajan (1974). Desain 4D terdiri dari 4 tahap yaitu pendefinisian (Define), perancangan (Design), pengembangan (Develop) dan penyebaran (Desiminate). Penelitian ini dilaksanakan: kegiatan tahap define. Tahap define melakukan analisis studi kebutuhan berupa kegiatan observasi pembelajaran dan wawacara terhadap guru dan siswa. Selanjutnya, tahap design adalah merancang produk berupa MOKOSA berbasis pendekatan STEM. MOKOSA yang disusun dengan teknik komik dan STEM. Kemudian, tahap development (Pengembangan) development adalah kegiatan membuat rancangan menjadi produk dan menguji validitas produk secara berulang ulang sampai dihasilkan produk sesuai dengan spesifikasi yang ditetapkan. Pada tahap ini meliputi (a) validasi ini dilakukan oleh ahli media, ahli materi dan guru yang berkompeten untuk memberikan penilaian dan saran pada produk ; (b) uji coba kelompok kecil atau terbatas; (c) uji coba terbatas dilakukan pada 8 siswa kelas V SD sebagai subjek uji coba yang masingmasing mewakili kemampuan dari berbagai tingkatan (d) Uji coba lapangan dilakukan pada kelas eksperimen. Pada tahap ini menggunakan desain eksperimen nonequivalent group design. Tahap terakhir dalam penelitian ini yaitu Dissemination (Diseminasi). Tahap dissemination (diseminasi) yaitu kegiatan menyebarluaskan produk yang telah teruji untuk dimanfaatkan orang lain. Tahap ini merupakan tahap penggunaan perangkat yang telah dikembangkan pada skala yang lebih luas, misalnya dikelas lain, di sekolah lain dan dengan guru yang berbeda. Pada tahap ini hanya dilaksanakan melalui pembuatan jurnal dan memberikan perangkat ke pihak sekolah.

\section{e. Data, Instrumen dan Teknik Pengumpulan Data}

Instrumen yang digunakan untuk mengumpulkan data pada penelitian ini adalah lembar angket untuk validasi media dan siswa untuk menilai produk yang dikembangkan, pedoman wawancara untuk guru dan siswa untuk melakukan studi pendahuluan, dan soal pretses dan posttest digunakan untuk mengukur hasil belajar.

\section{f. Teknik Analisis Data}

Teknik analisis data yang digunakan analisis deskriptif kuantitatif yaitu data kuantitatif yang diperoleh melalui angket validasi di konversikan ke data kualitatif. Adapun Pengubahan skor skala lima mengacu pada pengkategorisasian berikut ini.

Tabel. 1. Pengkategorisasian skor skala lima

\begin{tabular}{cccc}
\hline No & Rentang Skor & Skor & Kategori \\
\hline 1 & $\mathrm{X}>\mathrm{Xi}+1,8 \mathrm{Sbi}$ & $>4,2$ & Sangat Baik \\
2 & $\mathrm{Xi}+0,6 \mathrm{Sbi}<\mathrm{X} \leq \mathrm{Mi}+1,8 \mathrm{Sbi}$ & $>3,4-4,2$ & Baik \\
3 & $\mathrm{Xi}-0,6 \mathrm{Sbi}<\mathrm{X} \leq \mathrm{Mi}+0,6 \mathrm{Sbi}$ & $>2,6-3,4$ & Cukup \\
4 & $\mathrm{Xi}-1,8 \mathrm{Sbi}<\mathrm{X} \leq \mathrm{Mi}-0,6 \mathrm{Sbi}$ & $>1,8-2,6$ & Kurang \\
5 & $\mathrm{X} \leq \mathrm{Xi}-1,8 \mathrm{Sbi}$ & $\leq 1,8$ & Sangat kurang \\
\hline
\end{tabular}

Sumber: Widoyoko (2016:238)

Keterangan :

$\mathrm{X}=$ skor aktual (skor yang dicapai)

$\mathrm{Xi} \quad=$ rerata skor ideal $=(1 / 2)($ skor tertinggi ideal + skor terendah ideal $)$

Sbi = simpangan baku skor ideal

$=(1 / 6)$ (skor tertinggi ideal - skor terendah ideal 


\section{HASIL DAN PEMBAHASAN}

Data penelitian yang sudah diperoleh pada tahap define dan design dan tahap development. Hasil penelitian sebagai berikut.

\section{a. Tahap Define}

Tahap define dilakukan studi pendahuluan dengan memberikan angket kepada guru melalui layanan google form. Hasil studi pendahuluan dengan memberikan form kepada responden guru SD. Hasil studi pendahuluan diperoleh informasi.

1) Pendidikan sangat STEM penting diberikan kepada siswa karena memberikan pengetahuan yang menyeluruh antar disiplin ilmu.

2) Mayoritas guru responden penelitian belum mendapatkan pelatihan pembelajaran STEM.

3) Mayoritas guru belum menyusun media pembelajaran berpendekatan STEM.

4) Pembelajaran STEM dapat diintegrasikan di sekolah dasar, karena pembelajaran dilaksanakan secara tematik.

5) Perlu media pembelajaran yang dapat meningkatkan motivasi siswa untuk menggali informasi antar mata pelajaran yang mengemas STEM.

6) Komik diduga memiliki daya tarik untuk siswa sehingga rasa ingin tahu membaca buku semakin meningkat.

7) Modul STEM berbasis komik diperlukan untuk meningkatkan rasa ingin tahu dan motivasi siswa mengkaji antar bidang kajian.

Berdasarkan hasil studi pendahulan, peneliti menyimpulkan pentingnya media pembelajaran yang menghubungkan antar mata pelajaran/bidang kajian. Senada dengan pendapat Permanasari (2016) Pembelajaran berbasis STEM dapat melatih siswa dalam menerapkan pengetahuannya untuk membuat desain sebagai bentuk pemecahan masalah terkait lingkungan dengan memanfaatkan teknologi. Komik memiliki kontribusi yang besar dalam memberikan informasi yang mendidik, menghibur, sekaligus mempegaruhi seperti hakekat fungsi dari komunikasi (Maharsi, 2010: 10). Menurut Daryanto (2013: 128) kelebihan komik sebagai media pembelajaran, mengandung unsur visual dan cerita yang kuat. Ekspresi yang divisualisasikan membuat pembaca terlibat secara emosional membuat pembaca terdorong untuk membacanya hingga selesai.Penelitian yang dilakukan. Nugroho (2013) menyimpulkan komik SAINS yang dikembangkan juga terbukti efektif meningkatkan hasil belajar siswa. Penelitian Wijiati (2010) menyimpulkan multimedia komik pada pembelajaran matematika yang dikembangkan dapat digunakan sebagai sumber belajar siswa SD yang efektif. Rahmawati (2015) menyimpulkan media komik layak digunakan sebagai media pembelajaran kerena mampu meningkatan kemampuan bahasa Indonesia di kelas bahasa Indonesia untuk penutur asing tingkat dasar. Haryadi \& Irawan (2016) media komunikasi visual baik berupa media statis seperti komik dan cerita bergambar dapat diadaptasi untuk mendukung kegiatan storytelling sesuai dengan pesan yang ingin disampaikan. Rahmawati (2012) mengatakan bahwa strategi cerita sosial secara akurat mendeskripsikan situasi-situasi dan percakapan komik yang murni menggunakan simbol-simbol visual, konsep percakapan yang abstrak dan warna yang mengindikasi content emosional dapat meningkatkan pemahaman siswa.

\section{b. Tahap Design (merancang)}

Berdasarkan hasil studi pendahuluan, tahap berikutnya yaitu merancang produk media MOKOSA. Merancang produk diawali dengan menyusun story board dan menerjemahkan menjadi komik. Hasil tahap merancangan sebagai berikut.

\section{Merancang Story Board \\ Story Board}

Cover

Daftar Isi

Peta Konsep STEM

Petunjuk Penggunaan

Penokohan

Nama ku Tina: Aku siswa kelas 4 Sekolah Dasar. Aku satu kelompok dengan Dodi. 
Nama ku Dodi: Aku satu kelas dengan Tina. Aku dan Tina diberikan tugas oleh bu guru untuk mempeljari energy alternative. Dodi dan Tina membuka LKS pertama dan muncul pertanyaan.

1) Apa yang dimaksud energi altefnatif?

2) Apa saja contoh-contoh energi alternatif?

3) Mengapa biogas disebut energy alternatif?

4) Bagaimana Proses pembuatan Biogas?

5) Apakah terdapat perbedaan hasil biogas dari hewan dan tumbuhan?

6) Berapakah jumlah biogas yang dapat dihasilkan?

Dodi : Tina. Kamu tau jawabanya?

Tina : belum tau Dod, Aku cari informasi untuk menjawab soal dari buku dan kamu cari informasi dari Internet ya.

Seting : Dodi dan Tina sedang mencari informasi.

Dodi : Lihat Tina, Ini jawaban pertanyaan nomor 1. Sumber energi adalah segala sesuatu di sekitar kita yang mampu menghasilkan energy (setting sedang mengeja).

Tina : Dodi. Ini jawaban nomor 2.

Ditata seperti tabel:

1) Sel Surya Dari Matahari (bentuk gambar)

Sel surya adalah.....

2) Biosolar (bentuk gambar)

Biosolar adalah.....

3) Biogas adalah (bentuk gambar)

4) Dan lainnya dibawah diberikan keterangan

Tina : Dodi. Soal nomor 3, kamu sudah menemukan jawabannya?

Dodi : sebentar Tina, perutku lapar. Ayo kita makan bekal yang kita bawa dari rumah.

Tina : Dodi..Dodi tugas belum selesai, sudah minta istirahat. Ya sudah kita makan dulu.

Setting (mereka makan).

Dodi : Tina, tadi aku baca di internet kala biogas itu bisa dihasilkan dari tumbuhan atau kotoran hewan.

Tina : Dod!!. Kita lagi makan, jangan membahas kotoran!!

Dodi : maaf Tina. Tapi aku penasaran, mengapa biogas bisa dihasilkan dari apa yang kita makan dan kotoran hewan ya??

Tina : Sudah. Ayo selesaikan makan dan segera mengerjakan tugas.

Setting Dodi dan Tina sedang mengerjakan tugas kembali.

Dodi : Tina. Coba baca ini. Setting mereka mengeja.

Gambar biogas dan definisinya.

Dodi : Tina, Aku menemukan informasi cari membuat biogas.

Gambar proses pembuatan biogas.

Alat dan Baha, Langkah atau cara-cara membuat. (gambar).

Tina : Alhamdulilah. Kita mengetahui cara membuat biogas ya dodi.

Dodi : Tina. Menurut kamu, gas yang dihasilkan dari kotoran hewan dibandingkan dengan tumbuhan lebih manakah?

Tina : Aku juga belum tau dod. Ayo kita cari informasinya.

Setting Tina menemukan artikel hasil penelitian.

Tina : Dodi, Lihat hasil penelitian ini dod! Ternyata lebih baik ....dari pada ....

Gambar Tabel data hasil uji biogas, terdapat persen, angka decimal,

Dodi : Tina kalaw kita membuat biogas dari kotoran hewan sebsar $10 \mathrm{~kg}$ berapa......

Tina : Alhamdulilah Dod. Semua pertnyaan sudah dijawab semua.

Dodi : Belum selesai Tina. Ini masih ada kuis dari bu guru. Coba buka lembar jawabnya. 


\section{c. Tahap merancangan Produk MOKOSA}
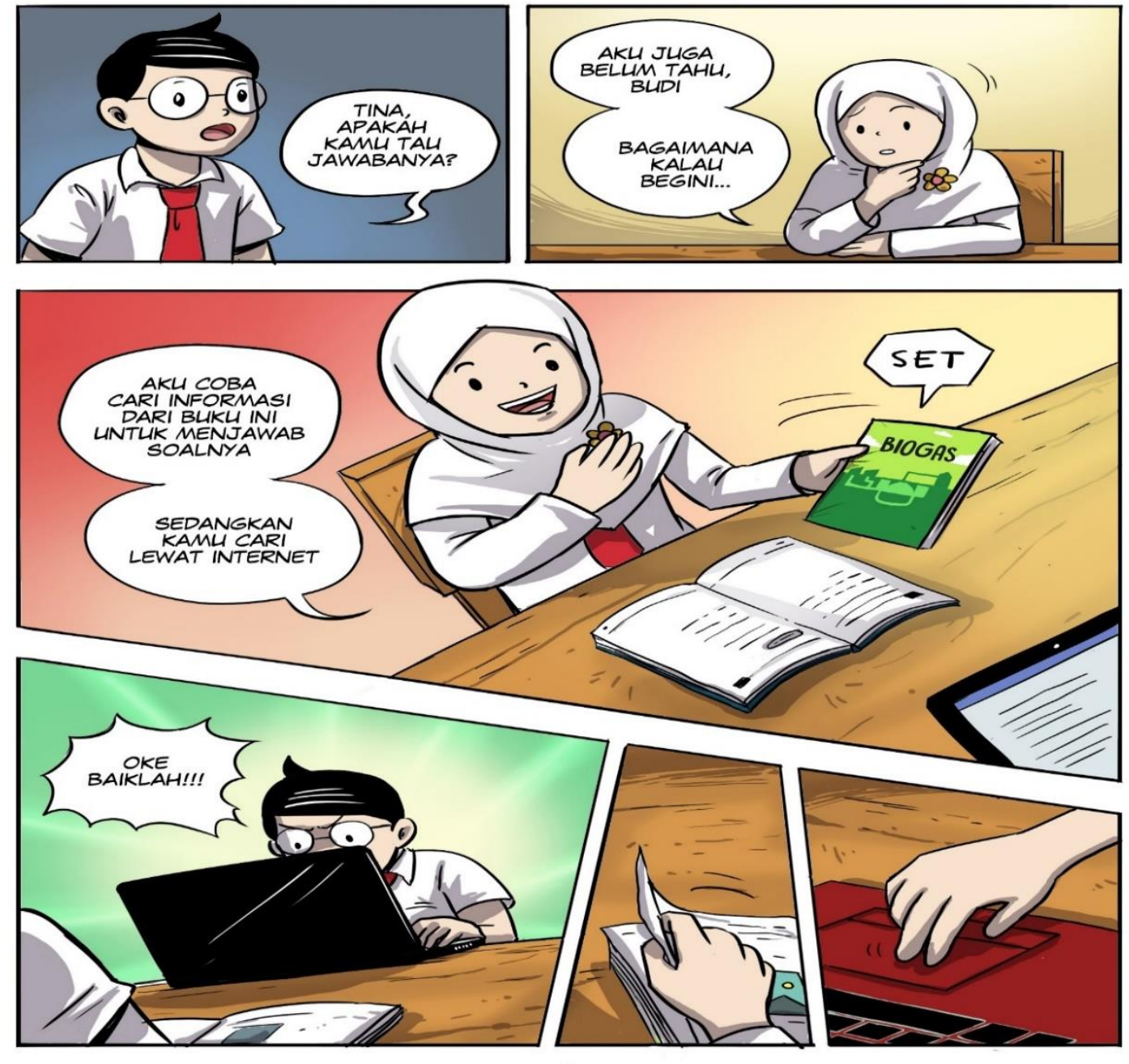

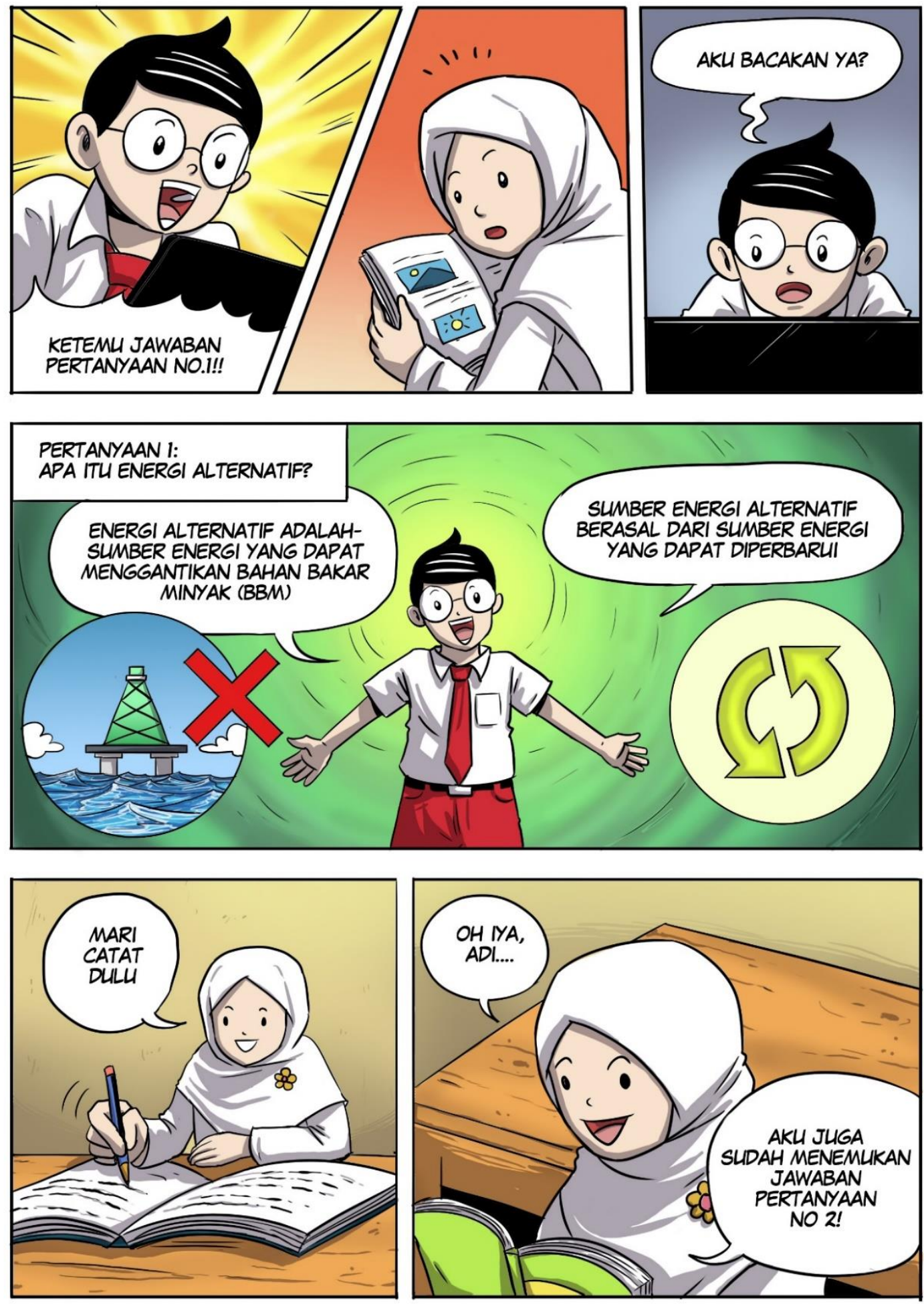

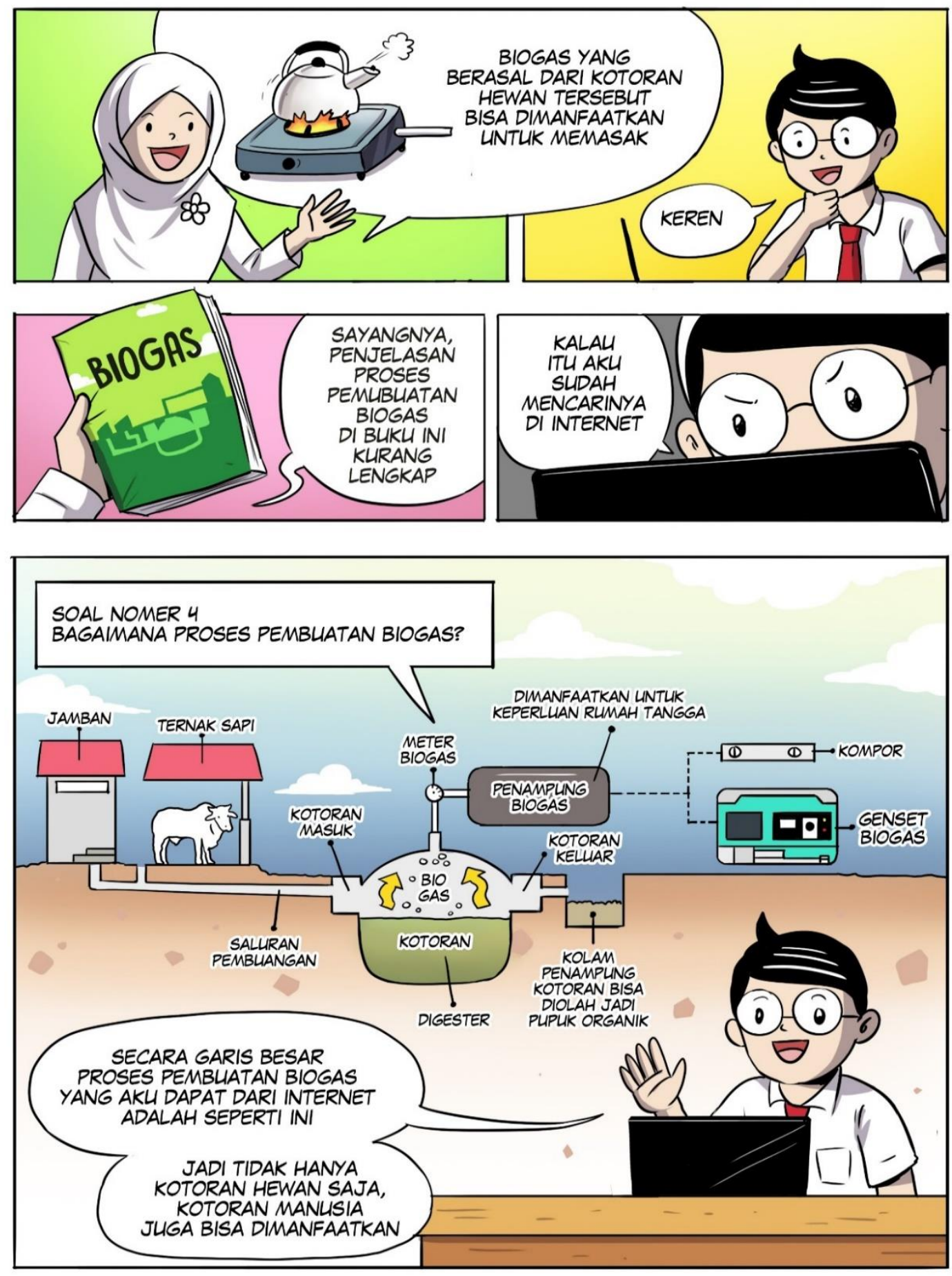

12

Gambar1. Contoh Produk Buku MOKOSA 
d. Validasi Produk

Hasil validasi yang diberikan oleh validator diperoleh informasi bahwa modul komik sains pendekatan STEM layak digunakan. Penilian validator terhadap produk yang dikembangkan ratarata "A" dengan predikat sangat baik. Penilaian validator disajikan dalam Tabel 1.

Tabel 1. Konversi Penilaian Validator

\begin{tabular}{|c|c|c|c|c|}
\hline No & Validator & $\begin{array}{l}\text { Rerata } \\
\text { Penilaian } \\
\text { Produk }\end{array}$ & Interval Skor & Nilai \\
\hline 1. & $\begin{array}{l}\text { Dosen } \\
\text { Teknologi } \\
\text { Pembelajaran }\end{array}$ & 3,8 & $\mathrm{X}>\mathrm{Xi}+1,5 \mathrm{Sbi}$ & A \\
\hline 2. & Dosen IPA & 4,3 & $\mathrm{Xi}+\mathrm{Sbi}<\mathrm{X}<\mathrm{Xi}+1,5 \mathrm{Sbi}$ & A \\
\hline 3. & Guru SD 1 & 3,9 & $\mathrm{Xi}-0,5 \mathrm{Sbi}<\mathrm{X}<\mathrm{Xi}+1,5 \mathrm{Sbi}$ & A \\
\hline 4. & Guru SD 2 & 4,2 & $\mathrm{Xi}-1,5 \mathrm{Sbi}<\mathrm{X}<\mathrm{Xi}-0,5 \mathrm{Sbi}$ & A \\
\hline 5. & Teman Sejawat & 4,4 & $\mathrm{X}<\mathrm{Xi}-1,5 \mathrm{Sbi}$ & A \\
\hline
\end{tabular}

Selain penilaian oleh validator berupa angka, validator memberikan penilaian berupa saran perbaikan terhadap produk. Saran yang diberikan oleh validator sebagai berikut:

1) Kalimat yang digunakan perlu memperhatikan EYD dan perkembangan siswa.

2) Aspek matematika perlu diberikan contoh dan latihan soal.

3) Perlu diberikan evaluasi dalam MOKOSA.

4) Karena pandemi, disediakan akses soft file dari produk ini.

\section{e. Uji Implementasi Produk}

Pelaksanaan uji produk MOKOSA di kelas 5 SD wilayah Brebes mengalami kendala. Adanya pandemi Covid 19, sekolah dasar di Brebes dari bulan Maret 2020 sampai Desember 2020 diberlakukan belajar dari rumah. Oleh karena itu, uji implementasi produk tidak dapat dilakukan.

Data yang diperoleh berdasarkan kegiatan penelitian langkah satu sampai empat. Studi pendahuluan diperoleh informasi bahwa penting dikembangkan media pembelajaran modul MOKOSA yang berpendekatan STEM. Alasannya, media yang mengitegrasikan aspek sains, teknologi, engenering dan matematika di SD belum ada. Selain itu, media LKS yang selama ini digunakan di SD tidak menarik karena bentuk tulisan dan tidak berwarna. Pertimbangan lainnya penting dikembangkan MOKOSA yaitu berdasarkan penelitian terdahulu tentang modul untuk siswa sekolah dasar dapat meningkatkan hasil belajar siswa. Hasil penelitian Nisa, Sarmini, Sudarmin (2015) disimpulkan bahwa siswa yang diajar dengan menggunakan modul terintegrasi etnosains dalam pembelajaran berbasis masalah memiliki kemampuan literasi sains lebih tinggi dibanding dengan kemampuan literasi sains kelas kontrol.Yanti, Sudarisman, Maridi (2016) disimpulkan bahwa karakteristik modul berbasis GIL sesuai sintaks GIL (observasi, manipulasi, generalisasi, verifikasi, dan aplikasi) dengan pendekatan sainstifik, layak, dan efektif untuk meningkatkan untuk meningkatkan literasi sains. Afriana, Permanasari, Fitriani (2016) tentang penerapan Project Based Learning terintegrasi STEM untuk meningkatkan literasi sains siswa. Rahmawati (2012) mengatakan bahwa strategi cerita sosial secara akurat mendeskripsikan situasi-situasi dan percakapan komik yang murni menggunakan simbol-simbol visual, konsep percakapan yang abstrak dan warna yang mengindikasi content emosional dapat meningkatkan pemahaman siswa.

Media pembelajaran MOKOSA memiliki karaktersitik berbasis komik. Penilaian semua validator disimpulkan MOKOSA layak digunakan untuk siswa SD. Unsur komik menjadi aspek yang penting dari media karena diduga meningkatkan minat peserta didik. Komik memiliki kontribusi yang besar dalam memberikan informasi yang mendidik, menghibur, sekaligus mempegaruhi seperti hakekat fungsi dari komunikasi (Maharsi, 2010: 10). Menurut Daryanto (2013: 128) kelebihan komik sebagai media pembelajaran, mengandung unsur visual dan cerita yang kuat. Ekspresi yang divisualisasikan membuat pembaca terlibat secara emosional membuat pembaca terdorong untuk 
membacanya hingga selesai..Penelitian yang dilakukan. Nugroho (2013) menyimpulkan komik sains yang dikembangkan juga terbukti efektif meningkatkan hasil belajar siswa. Penelitian Wijiati (2010) menyimpulkan multimedia komik pada pembelajaran matematika yang dikembangkan dapat digunakan sebagai sumber belajar siswa SD yang efektif. Penggunaan komik dipilih dalam penelitian ini sebagai strategi untuk meningkatkan motivasi belajar siswa. Tampilan gambar pada komik memperkuat informasi yang disampaikan.Karakteristik siswa SD yang lebih mudah belajar menggunakan media gambar untuk menjelaskan sebuah konsep, menjadi pertimbangan alasan pemilihan teknik komik. Rahmawati (2012) mengatakan bahwa strategi cerita sosial secara akurat mendeskripsikan situasi-situasi dan percakapan komik yang murni menggunakan simbol-simbol visual, konsep percakapan yang abstrak dan warna yang mengindikasi content emosional dapat meningkatkan pemahaman siswa.

Karakteristik yang kedua dari media ini mengemas tema yang menyajikan STEM. Pendekatan STEM diduga tepat untuk menyusun modul yang bertujuan meningkatkan literasi sains siswa. Permanasari (2016) penerapan STEM cocok digunakan pada pembelajaran sains. Pembelajaran berbasis STEM dapat melatih siswa dalam menerapkan pengetahuannya untuk membuat desain. sebagai bentuk pemecahan masalah terkait lingkungan dengan memanfaatkan teknologi. Hasil penelitian Arfiana, Permanasari, Fitriani (2016) tentang penerapan Project Based Learning Terintegrasi STEM untuk Meningkatkan Literasi Sains Siswa Ditinjau dari Gender disimpulkan hasil terjadi peningkatan literasi sains siswa kelompok laki-laki dan kelompok perempuan samasama mengalami peningkatan dengan rerata N_Gainyaitu 0,36 dan 0,31pada kategori sedang untuk aspek pengetahuan dan kompetensi. Hasil penelitian Muharomah (2017) menyimpulkan terdapat pengaruh pembelajaran STEM terhadap hasil belajar siswa pada konsep evolusi. Ismayani (2016) disimpulkan bahwa terdapat perbedaan pencapaian kemampuan sebelum dan setelah pembelajaran berbeda secara signifikan.

Data penilaian validator terhadap MOKOSA disimpulkan sangat baik digunakan dalam pembelajaran di SD. Menurutnya, media yang dikembangkan memenuhi aspek pembelajaran STEM dan media komik yang mendukung siswa untuk mempelajari materi secara holistik. Hasil penilaian validator sebagai berikut.

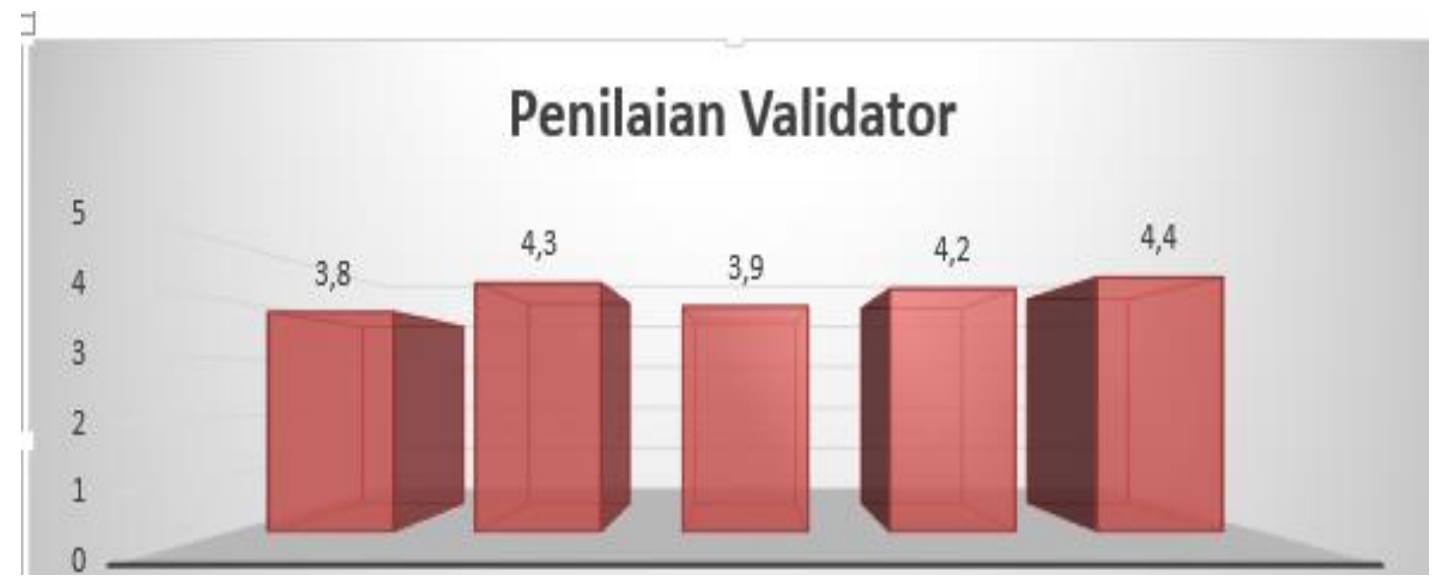

Gambar 3. Penilaian Validator 


\section{KESIMPULAN}

Berdasarkan hasil penelitian dan pembahasan dapat disimpulkan bahwa media MOKOSA berbasis STEM dikembangkan melalui tahap 4D yang terdiri dari define, design, develop dan dissemination layak dan valid digunakan di lapangan. Berdasarkan persepsi responden yakni 167 guru pada SMP Negeri di Kecamatan Pemalang tentang motivasi kerja guru diperoleh jumlah skor 29253, skor rata-rata 175,17. Kategori persepsi motivasi kerja guru dapat dilihat pada tabel 1.

\section{DAFTAR PUSTAKA}

Arfiana, Jaka., Permanasari, A., Fitriana, A. 2010. Penerapan project based learning terintegrasi STEM untuk meningkatkan literasi sains siswa ditinjau dari gender, Jurnal Inovasi Pendidikan IPA, 2(2):202-212

Borg, W.R. \& Gall, M.D (1983). Educational Research: Longman, New York London

Darmiatun. 2013. Menyusun Modul Bahan Ajar untuk Persiapan Guru dalam Mengajar. Yogyakarta: Gava Media.

Daryanto. (2010). Media Pembelajaran Peranannya Sangat Penting dalam Mencapai Tujuan Pembelajaran. Yogyakarta: Gava Media.

Hake, R.R.(1998). Interactive-engagment versus traditional methods: a sixthousand student survey of mechanics test data for introductory physics courses. American Journal of Physics Research. 66 (1), 66-74

Haryadi, Toto, Irawan, D.I.U. (2016). Penanaman Nilai dan Moral pada Anak Sekolah Dasar dengan Pendekatan Storytelling Melalui Media Komunikasi Visual. Jurnal Andhorupa, 2 (1)

Ismayani, Ani. 2016. Pengaruh Penerapan STEM PROJECT-BASED LEARNING TERHADAP KREATIVITAS MATEMATIS SISWA SMK. Cianjur : Indonesian Digital Journal of Mathematics and Education, 3 (4)

Madjid, Abdul (2014).Pembelajaran Tematik Terpadu. Bandung: Remaja Rosdakarya.

Maharsi, Indria. (2010). Komik dunia kreatif tanpa batas. Yogyakarta: Kata Buku

Mardapi, D. (2008). Teknik Penyusunan Instrumen Tes dan Nontes. Yogyakarta: MITRA CENDIKIA Press

Mulyatiningsih, Endang. (2010). Pembelajaran Aktif, Kreatif, Inovatif, Efektif, dan Menyenangkan. Dirjen Jendral Peningkatan Mutu Pendidik dan Tenaga Kependidikan Kemendikbud

Muharomah, Dewi Robiatun. 2017. Pengaruh Pembelajaran Science, Technology, Engineering and Mathematics (STEM) Terhadap Hasil Belajar Peserta Didik Pada Konsep Evolusi. Fakultas Ilmu Tarbiyah dan Keguruan Universitas Islam Negeri Syarif Hidayatullah: Jakarta.

Nisa, Sarmini, Sudarmin. 2015. Efektivitas Penggunaan Modul Terintegrasi Etnosains dalam Pembelajaran Berbasis Masalah untuk Meningkatkan Literasi Sains Siswa. Semarang: Unnes Science Education Journal 4(3:1409-1456

Nurdiyanti, Eko \& Suryanto Edy. 2010. Pembelajaran Literasi Mata Pelajaran Bahasa Indonesia pada Siswa Kelas V Sekolah Dasar. Paedagogia, 13 (2):115-128.

Permanasari, Anna. 2016. STEM Education : Inovasi dalam Pembelajaran Sains. Bandung: Prosiding Seminar Nasional Pendidikan Sains.

Rahmawati, Dewi. 2012. Analisis Literasi Sains Siswa SMP Dalam Pembelajaran Ipa Terpadu Pada Tema Penerapan Bioteknologi Konvensional. S1 Skripsi. UPI. Bandung. 
Rusman, (2010). Model-Model Pembelajaran:Mengembangkan Profesionalisme Guru. Jakarta: Rajawali Pers.

Tjalla, A W. (2010). Potret Mutu Pendidikan Indonesia Ditinjau dari Hasil-hasil Studi Internasional. Prosiding Seminar Nasional. Diakses dari http://repository.ut.ac.id/2609/1/fkip201047.pdf

Wijiati,Tenni, Syafik, Abu, Purwoko, Y.R(2010). Pengembangan Multimedia Komik Pembelajaran Matematika Berbasis Pendekatan Kontekstual Untuk Siswa Sekolah Dasar. Skripsi. Tidak Diterbitkan. UIN SUKA: Yogyakarta.

Winarni, Zubaedah, dan Supriyono. (2016). STEM : Apa, Mengapa, dan Bagaimana. Jurnal Prosiding Seminar Nasional Pendidikan IPA Pancasarjana UM Malang, No 1. Tahun 2016.

Yanti, I.W., Sudarisman,S, Maridi. 2016. Pengembangan modul berbasis guided inquiry laboratory (gil) untuk meningkatkan literasi sains dimensi konten. Jurnal inkuiri. 5(2):109.

http://jurnalnasional.ump.ac.id/index.php/khazanah 